\title{
EFFECT OF SYNTHETIC OR HERBAL PRESERVATIVES ON THE QUALITY OF BEEF MEATBALLS AT DIFFERENT SHELF LIFE PERIODS
}

\author{
F. Islam, M.A. Hossain, M.F. Rahman, M.A. Hashem*, \\ M. Rahman and M.A.K. Azad \\ Department of Animal Science, Bangladesh Agricultural University, Mymensingh, Bangladesh
}

\begin{abstract}
The experiment was conducted to compare the effect of Moringa oleifera leaf extract with synthetic antioxidant on beef meatball. Five types of beef meatballs were formulated for this purpose. Meatballs were made with control (0\%), 0.1\% Beta Hydroxyl Anisole (BHA), 0.1, 0.2 and $0.3 \%$ Maringa oleifera leaf extract, respectively. Quality and safety evaluation of meatballs were determined by sensory, physiochemical, biochemical and microbiological tests. After preparation meatballs were preserved at $-20^{\circ} \mathrm{C}$. The analyses were conducted at $0,15^{\mathrm{t}}, 30$ and 60 days of interval. An ANOVA of a $5 \times 4$ factorial experiment in completely randomized design having three replications per treatment was used for the analyses of data. Considering $\mathrm{CP}$, tenderness, juiciness, overall acceptability, cooking loss, FFA, POV and TBARS value it can be concluded that Moringa oleifera leaf extract up to a level of $0.3 \%$ may replace $\mathrm{BHA}$ for meatball preservation without deteriorating its quality. In case of sensory evaluation $0.2 \%$ Moringa leaf extract shows better results. But on the basis of nutrient quality, physicochemical properties, biochemical analysis and microbial analysis $0.3 \%$ Moringa leaf extract group is more satisfactory than other treatment groups.
\end{abstract}

Keywords: Antioxidant, BHA, beef meatball, Maringa oleifera leaf, shelf life.

\section{INTRODUCTION}

Lipid per-oxidation causes meat spoilage. It occurs during processing and storage when meatballs are exposed to oxygen, heat, and light (Fasseas et al., 2007). Antioxidants have an ability to prevent or reduce the oxidative damage of a tissue indirectly by enhancing natural defense of cell and/or directly by scavenging free radical species (Verma et al., 2009). Over the years, synthetic antioxidants such as, beta hydroxyl anisole, butyrate hydroxyl toluene and tertiary butyl hydroquinone

\footnotetext{
*Corresponding author email: hashem_as@bau.edu.bd
} 
have been widely used to preserve meat and meat products (Fasseas et al., 2007). The use of these antioxidants is questionable since they have been discovered to have toxic, mutagenic and/or carcinogenic effects on human and animals (Hayes et al., 2010). There has been a growing interest in the use of natural antioxidants as alternatives to synthetic antioxidants. In addition, consumers` interests to natural antioxidants have been growing, considering them safer than the synthetics (Jung et al., 2010). It has also been reported that natural antioxidants, especially of plant source, have greater application potential for consumer's acceptability, palatability, stability and supporting longer shelf-life of meat products (Jung et al., 2010). Moringa oleifera is the most widely cultivated species of the Moringaceae family in Bangladesh. As a nutritious tree, it has various function including pharmacological and antioxidant properties (Verma et al., 2009). Phenolics and flavonoids are the authentic antioxidants found in moringa leaf that have been reported to be safe and bioactive (Sreelatha and Padma, 2009). No investigation, so far been done, on the effect of different levels of Moringa leaf extracts on beef meatball, in terms of their quality at different shelf-life. The present study was, thus, undertaken to investigate the effect of using Moringa (Moringa oleifera) leaf extract on the quality of beef meatballs at different storage periods compared to using Beta Hydroxylanisole (BHA).

\section{MATERIALS AND METHODS}

The study was conducted during the period of January, 2014 to December, 2014 in the Department of Animal science, Bangladesh Agricultural University, Mymensingh. The beef sample was collected from the local market of Mymensingh. Meatballs were prepared using fresh beef, garlic pest, onion pest, ginger pest, meat spices, garam masala (spices), egg, biscuit crumbs, soybean oil, ice flakes, refined vegetable oil, refined wheat flower, Moringa oleifera leaf extract, BHA, salt and sauces. There were five treatment groups i.e. control (To), meatball with $0.1 \%$ BHA (T1), $0.1,0.2$ or $0.3 \%$ Moringa oleifera leaf extract as $\mathrm{T}_{2}, \mathrm{~T}_{3}, \mathrm{~T}_{4}$, respectively. Sensory qualities (Color, flavor, tenderness, juiciness and overall acceptability) were evaluated by a trained 6-member panel. Samples were evaluated after cooking. When internal temperature of meat reached at $71^{\circ} \mathrm{C}$ then cooking was finished and it was checked by a food grade thermometer. After that meat sample was used for sensory evaluation using a 5-point scoring method that ranks the panelist's sense of qualities. Sensory scores were 5 for excellent, 4 for very good, 3 for good, 2 for fair and 1 for poor. All samples were served in Petri dishes. Sensory evaluation was accomplished at 0 day and repeated at 15, 30 and 60 day. The Dry Matter, Ether Extract, Crude Protein and Ash of meatballs were determined using the method described by AOAC, (1995). The $\mathrm{pH}$ of raw and cooked meatball was determined using a $\mathrm{p}^{\mathrm{H}}$ meter. The cooking loss of meatballs was also determined by a weighing balance and a hot water bath. FFA value, POV value and TBARS value were determined by Sharma et al. (2012). TVC, TCC and TYMC were determined according to Ikhlas et al. (2011).All determination was done in triplicate and a mean value was reported. 


\section{Statistical analysis}

Data were analyzed using SAS Statistical package by $5 \times 4$ factorial experiments in CRD having three replications per treatment. Five factors were five treatment groups like control (To) and $0.1 \%$ BHA (T1), $0.1,0.2$ or $0.3 \%$ Moringa oleifera leaf extract as $T_{2}, T_{3}, T_{4}$. Four days of intervals as $0,15,30$ and 60 days as level. Altogether there were 40 treatment combinations in $5 \times 4$ factorial experiment. DMRT test was used to determine the significance of differences among treatment means.

\section{Sensory evaluation}

\section{RESULTS AND DISCUSSION}

It was found that sensory quality after fortification with Maringa leaf extracts was improved. The range of overall observed color, odor, tenderness, juiciness and overall acceptability score was 3.55 to $4.50,3.55$ to $4.42,3.73$ to $4.75,3.73$ to 4.75 and 3.55 to 4.17 , respectively (Table 1). From the data it shows that Maringa leaf extracts level significantly $(\mathrm{p}<0.05)$ increase the overall acceptability. The most preferable color observed at 0 day and less preferable color at 60 day. The range of color, odor, tenderness, juiciness and overall acceptability among different days of interval was 3.00 to $4.71,3.00$ to $4.71,3.60$ to $4.79,3.60$ to 4.79 and 2.87 to 4.64 respectively. Among these five treatments most preferable color, flavor, and overall acceptability was observed at $\mathrm{T}_{3}(0.2 \%)$ and most preferable tenderness and juiciness was found at $\mathrm{T}_{4}(0.3 \%)$ Moringa leaf extract group, respectively. Present findings is in agreement with Gonzalez et al. (2008) where he stated that dried plum ingredients in raw and precooked pork sausage positively effect the sensory attributes viz. color, texture, odor, and flavor as well as nutritional quality of the product.

\section{Proximate analysis}

From table 2 overall DM content at different treatment was 58.13 to $54.11 \%$. The highest and the lowest DM content observed at 0 day and 60 day, respectively. The highest DM content indicates this product is less preferable. DM content increased with increased storage period because moisture loss decreased with storage period. Similar results were reported for Indonesian traditional meatballs with a moisture content ranged from 69.52 to $71.17 \%$ (Purnomo and Rahardiyan, 2008). CP content at different treatments was 21.89 to $23.00 \%$. The maximum CP content was observed at $0.3 \%$ Moringa leaf extract group. $\mathrm{CP}$ content at different days of interval was 23.25 to $22.10 \%$. Gradual loss of DM and CP over the days of intervals was due to loss of moisture during storage. EE content at different treatments was 11.38 to $12.06 \%$. Synthetic antioxidant group contain lower amount of EE than control group. The most preferable EE content was observed at $\mathrm{T}_{4}(0.3 \%)$ Moringa leaf extract group. The range of EE content at different days of interval was 11.83 to $11.84 \%$. The most preferable EE content was observed at 0 day and less preferable EE content at 60 day (Table 2). Serdaroglu et al. (2005) reported a similar fat content ranged from 7.9 to $8.8 \%$ in low-fat traditional Turkey koefte beef meatballs. Overall ash content at different treatments was 3.63 to $3.74 \%$. Synthetic antioxidant group contain lower amount of ash than control group. 
Table 1. Effect of Moringa oleifera leaf extract and BHA on sensory parameters in beef meatball

\begin{tabular}{|c|c|c|c|c|c|c|c|c|c|c|}
\hline \multirow{2}{*}{ Parameter } & \multirow{2}{*}{ DI } & \multicolumn{5}{|c|}{ Treatments } & \multirow{2}{*}{ Mean } & \multicolumn{3}{|c|}{ Level of Significance } \\
\hline & & $\mathrm{T}_{0}$ & $\mathrm{~T}_{1}$ & $\mathrm{~T}_{2}$ & $\mathrm{~T}_{3}$ & $\mathrm{~T}_{4}$ & & Treat & DI & $\mathrm{T} * \mathrm{DI}$ \\
\hline \multirow[t]{5}{*}{ Color } & 0 & $4.50 \pm 0.50$ & $4.67 \pm 0.33$ & $4.67 \pm 0.33$ & $5.00 \pm 0.00$ & $4.67 \pm 0.33$ & $4.71^{\mathrm{a}} \pm 0.30$ & $\mathrm{p}<0.05$ & $\mathrm{p}<0.01$ & $\mathrm{p}>0.99^{\mathrm{ns}}$ \\
\hline & 15 & $4.33 \pm 0.33$ & $4.67 \pm 0.33$ & $4.67 \pm 0.03$ & $5.00 \pm 0.00$ & $4.67 \pm 0.33$ & $4.67^{\mathrm{a}} \pm 0.25$ & & & \\
\hline & 30 & $3.33 \pm 0.33$ & $3.67 \pm 0.33$ & $4.00 \pm 0.58$ & $4.33 \pm 0.33$ & $4.00 \pm 0.58$ & $3.87^{\mathrm{b}} \pm 0.54$ & & & \\
\hline & 60 & $2.33 \pm 0.33$ & $3.00 \pm 0.00$ & $3.33 \pm 0.23$ & $3.67 \pm 0.33$ & $3.33 \pm 0.33$ & $3.13^{\mathrm{c}} \pm 0.30$ & & & \\
\hline & Mean & $3.55^{\mathrm{a}} \pm 0.37$ & $4.00^{\mathrm{ab}} \pm 0.25$ & $4.17^{\mathrm{a}} \pm 0.28$ & $4.50^{\mathrm{a}} \pm 0.16$ & $4.17^{\mathrm{a}} \pm 0.31$ & & & & \\
\hline \multirow{4}{*}{ Flavor } & 15 & $4.33 \pm 0.33$ & $4.67 \pm 0.33$ & $4.67 \pm 0.33$ & $5.00 \pm 0.00$ & $4.67 \pm 0.33$ & $4.67^{\mathrm{a}} \pm 0.32$ & & & \\
\hline & 30 & $3.33 \pm 0.33$ & $3.67 \pm 0.33$ & $4.00 \pm 0.58$ & $4.33 \pm 0.33$ & $4.67 \pm 0.33$ & $4.00^{\mathrm{b}} \pm 0.45$ & & & \\
\hline & 60 & $2.33 \pm 0.33$ & $2.67 \pm 0.33$ & $3.00 \pm 0.00$ & $3.33 \pm 0.33$ & $3.67 \pm 0.33$ & $3.00^{\mathrm{c}} \pm 0.33$ & & & \\
\hline & Mean & $3.55^{\mathrm{a}} \pm 0.35$ & $3.92^{\mathrm{ab}} \pm 0.32$ & $4.08^{\mathrm{a}} \pm 0.31$ & $4.42^{\mathrm{a}} \pm 0.16$ & $4.42^{\mathrm{a}} \pm 0.32$ & & & & \\
\hline \multirow[t]{2}{*}{ Tenderness } & 0 & $4.50 \pm 0.50$ & $4.67 \pm 0.33$ & $4.67 \pm 0.33$ & $5.00 \pm 0.00$ & $5.00 \pm 0.00$ & $4.79^{\mathrm{a}} \pm 0.27$ & $\mathrm{p}<0.01$ & $\mathrm{p}<0.01$ & $\mathrm{p}>0.76^{\mathrm{ns}}$ \\
\hline & Mean & $3.73^{\mathrm{c}} \pm 0.35$ & $4.17^{\mathrm{bc}} \pm 0.25$ & $4.33^{\mathrm{ab}} \pm 0.35$ & $4.67^{\mathrm{a}} \pm 0.20$ & $4.75^{\mathrm{a}} \pm 016$ & & & & \\
\hline \multirow[t]{5}{*}{ Juiciness } & 0 & $4.50 \pm 0.50$ & $4.67 \pm 0.33$ & $4.67 \pm 0.33$ & $5.00 \pm 0.00$ & $5.00 \pm 0.00$ & $4.79 a \pm 0.24$ & $\mathrm{p}<0.01$ & $\mathrm{p}<0.01$ & $\mathrm{p}<0.94 \mathrm{~ns}$ \\
\hline & 15 & $4.67 \pm 0.33$ & $4.67 \pm 0.33$ & $4.67 \pm 0.33$ & $5.00 \pm 0.00$ & $5.00 \pm 0.00$ & $4.80 \mathrm{a} \pm 0.19$ & & & \\
\hline & 30 & $3.33 \pm 0.33$ & $3.67 \pm 0.33$ & $4.00 \pm 0.58$ & $4.33 \pm 0.33$ & $4.67 \pm 0.33$ & $4.07 b \pm 0.54$ & & & \\
\hline & 60 & $2.67 \pm 0.33$ & $3.33 \pm 0.33$ & $3.67 \pm 0.33$ & $4.00 \pm 0.58$ & $4.33 \pm 0.33$ & $3.60 c \pm 0.42$ & & & \\
\hline & Mean & $3.73 c \pm 0.37$ & $4.08 b c \pm 0.33$ & $4.25 \mathrm{abc} \pm 0.38$ & $4.58 \mathrm{ab} \pm 0.23$ & $4.75 a \pm 0.16$ & & & & \\
\hline \multirow{5}{*}{$\begin{array}{l}\text { Overall } \\
\text { acceptability }\end{array}$} & 0 & $4.50 \pm 0.50$ & $4.67 \pm 0.33$ & $4.67 \pm 0.33$ & $4.67 \pm 0.33$ & $4.67 \pm 0.33$ & $4.64 \mathrm{a} \pm 0.40$ & $\mathrm{p}<0.05$ & $\mathrm{p}<0.01$ & $\mathrm{p}>0.99 \mathrm{~ns}$ \\
\hline & 15 & $4.33 \pm 0.33$ & $4.67 \pm 0.33$ & $4.67 \pm 0.33$ & $5.00 \pm 0.00$ & $4.67 \pm 0.33$ & $4.67 a \pm 0.26$ & & & \\
\hline & 30 & $3.33 \pm 0.33$ & $3.67 \pm 0.33$ & $4.00 \pm 0.58$ & $4.33 \pm 0.33$ & $4.33 \pm 0.33$ & $3.93 b \pm 0.38$ & & & \\
\hline & 60 & $2.33 \pm 0.33$ & $2.67 \pm 0.33$ & $3.00 \pm 0.00$ & $3.33 \pm 0.33$ & $3.00 \pm 0.58$ & $2.87 c \pm 0.31$ & & & \\
\hline & Mean & $3.55 \mathrm{~b} \pm 0.35$ & $3.92 \mathrm{ab} \pm 0.32$ & $4.08 \mathrm{a} \pm 0.31$ & $4.33 \mathrm{a} \pm 0.25$ & $4.17 \mathrm{a} \pm 0.38$ & & & & \\
\hline
\end{tabular}


Table 2. Effect of Moringa oleifera leaf extract and BHA on proximate components in beef meatball

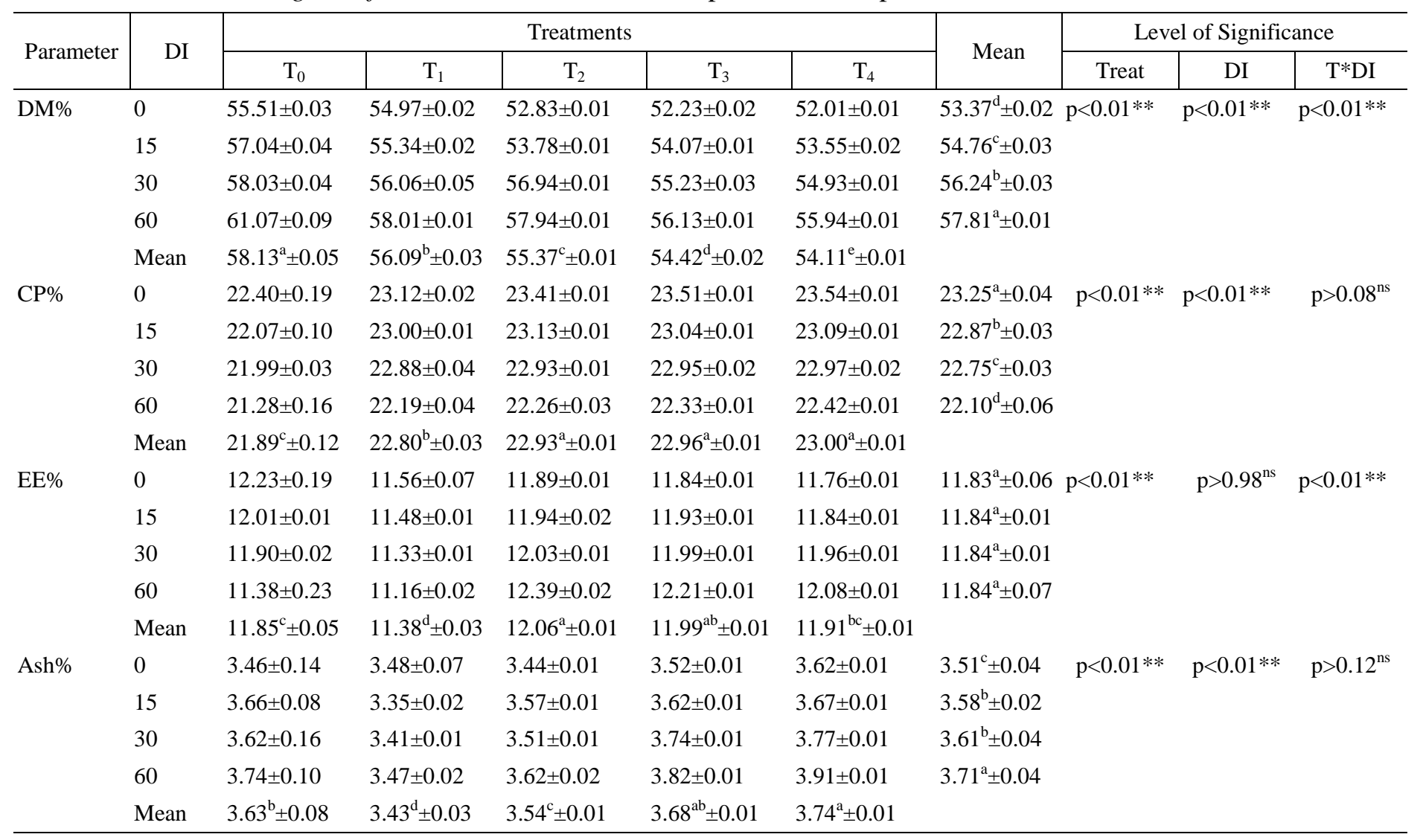


F. Islam et al.

\section{Physicochemical properties}

The range of overall observed raw $\mathrm{pH}$ at different treatments was 5.68 to $6.04 \%$. Among five treatments most preferable raw $\mathrm{pH}$ was observed at $\mathrm{T}_{4}(0.3 \%)$ Moringa leaf extract group (Table 3). The highest amount of raw meat $\mathrm{pH}$ indicates this product is most preferable for consumers' health. Raw $\mathrm{pH}$ among these treatments was decreased with increased storage period $(\mathrm{p}<0.01)$. Raw $\mathrm{p}^{\mathrm{H}}$ at different days of interval was 6.05 to $5.72 \%$. The most preferable raw $\mathrm{p}^{\mathrm{H}}$ was observed at 0 day and less preferable was observed at 60 day. Overall cooked $\mathrm{p}^{\mathrm{H}}$ at different treatments was 5.87 to 6.15 . The most preferable cooked $\mathrm{p}^{\mathrm{H}}$ was observed at $\mathrm{T}_{5}(0.3 \%)$ Moringa leaf extract group. Irrespective of treatments $\mathrm{pH}$ had significantly increased $(\mathrm{p}<0.01)$ with the increased level of Moringa leaf extracts. This is may be due to alkaline nature of herbal extracts. On the other hand with the increase of days of intervals $\mathrm{pH}$ had decreased significantly $(p<0.01)$ in all treatment groups. Similar results have also been found in the study of antioxidant treatments during storage time using a mixture of BHA and BHT in precooked pork patties (Biswas et al., 2004). The overall cooking loss at different treatments was 24.21 to $23.96 \%$. The highest cooking loss was observed at $\mathrm{T}_{1}(0 \%)$ Moringa leaf extract group. The overall cooking loss at different days of interval was 26.19 to $21.78 \%$. The lowest cooking loss was observed at 0 day and the highest cooking loss was observed at 60 day of observation $(\mathrm{p}<0.01)$. Cooking loss refers to the reduction of weight of meatballs during cooking process (Jama et al., 2008) is the similar trend with this experiment. From the study it reveals that treated Moringa leaf extracts had significantly reduced $(\mathrm{p}<0.01)$ cooking loss compared to control group.

\section{Biochemical properties}

From table 4 the overall FFA, POV and TBARS value at different treatment was 0.45 to $0.35,4.54$ to 4.17 and 0.58 to 0.46 , respectively. The overall FFA, POV and TBARS at different days of interval were 0.34 to $0.44,3.96$ to 4.59 and 0.39 to 0.64 , respectively. The most preferable FFA value observed at 0 day and less preferable FFA observed at 60 day observation. The FFA value $(0.45)$ in the control group was significantly $(p<0.01)$ higher than the values of the samples treated with BHA, 0.1, 0.2 , and $0.3 \%$ Moringa oleifera leaf extract. Lee and Kunz (2005) found that fermented sausages showed an increasing FFA content over time. It has been reported that these natural antioxidants, especially of plant source, have greater application potential for consumer's acceptability, palatability, stability and shelf-life of meat products (Jung et al., 2010). Throughout the storage time, POV were generally higher in control sample than in others. The most preferable POV was observed at $\mathrm{T}_{5}(0.3 \%)$ Moringa leaf extract group. The control sample, without any added antioxidants, showed a higher level of TBARS than samples treated with 0.1 , 0.2 , and $0.3 \%$ Moringa leaf extract or BHA. The TBARS level of samples treated with $0.1,0.2$, and $0.3 \%$ Maringa leaf extract was also lower than those treated with BHA; this difference was especially significant $(p<0.05)$ after 60 days of storage 
time. Natural antioxidants, in particular polyphenols, are the major plant compounds which have the ability to attenuate the oxidative damage of a tissue indirectly by enhancing natural defenses of cell and/or directly by scavenging the free radical species combat pathological disorders generated by physicochemical Reactive Oxygen Species (ROS) (Du et al., 2010). Antioxidants have an ability to prevent the oxidative damage of tissue indirectly by enhancing natural defenses of cell and directly by scavenging the free radical species (Verma et al., 2009). It has also been reported that these natural antioxidants, especially of plant source, have greater application potential for consumer's acceptability, palatability, stability and shelf-life of meat products (Jung et al., 2010). One such plant with a potential to be used as an antioxidant is Moringa leaf extracts. It has pharmacological activities and antioxidant properties. Sankhalkar and Vernekar (2016) reported that there are higher phenolics and flavanoid content in Moringa leaf and flower. From the present findings it shows that FFA, POV and TBARs value had significantly $(\mathrm{p}<0.01)$ reduced with the addition of Morigna leaf extracts compared to unsupplemented group. It had happened due to the presence of higher phenolics and flavanoid content in Moringa leaf.

\section{Microbiological assessment}

From table 5 TVC value of fresh beef was $5.12 \operatorname{logs} \mathrm{CFUg}^{-1}$ beef, indicates good quality beef. The overall aerobic plate count, TCC value and TYMC of beef meatball was 5.06-4.36 $\left(\log 10 \mathrm{CFUg}^{-1}\right), 1.10-0.91\left(\log \mathrm{CFUg}^{-1}\right)$, and 1.50 to $1.25\left(\log \mathrm{CFUg}^{-}\right.$ $\left.{ }^{1}\right)$, respectively at different treatment levels. Among the five treatments, the plate count in control sample $\left(5.06 \log \mathrm{CFUg}^{-1}\right)$ were significantly $(\mathrm{p}<0.01)$ higher than in the samples treated with BHA, $0.1,0.2$ and $0.3 \%$ of Moringa leaf extracts. The range of TVC value, TCC value and TYMC values at different days of interval was 4.45 to $4.86,1.12$ to 0.87 and 1.79 to 1.04 , respectively. All the microbial values had linearly decreased $(p<0.01)$ in the Moringa leaf extract treated groups compared to control groups. The TCC value of fresh beef was $1.25 \operatorname{logs} \mathrm{CFUg}^{-1}$ beef. Among these five treatments, the TCC in the control sample $\left(1.10 \operatorname{logs} \mathrm{CFUg}^{-1}\right)$ was significantly $(\mathrm{p}<0.01)$ higher than in the samples treated with BHA, 0.1, 0.2, and $0.3 \%$ of Moringa leaf extracts. The different superscript was observed from different treatment indicates there were significant differences of TYMC values among these five treatment groups. Among five treatments, the total yeast-mold count in the control sample $\left(1.50 \log \mathrm{CFUg}^{-1}\right)$ were significantly $(\mathrm{p}<0.05)$ higher than in the samples treated with BHA, 0.1, 0.2, and $0.3 \%$ of Moringa leaf extracts. Some bacteria may be present in the product, but their growth is controlled under storage conditions (Fernandez Lopez et al., 2005). 
Table 3. Effect of Moringa oleifera leaf extract and BHA on physicochemical properties in beef meatball

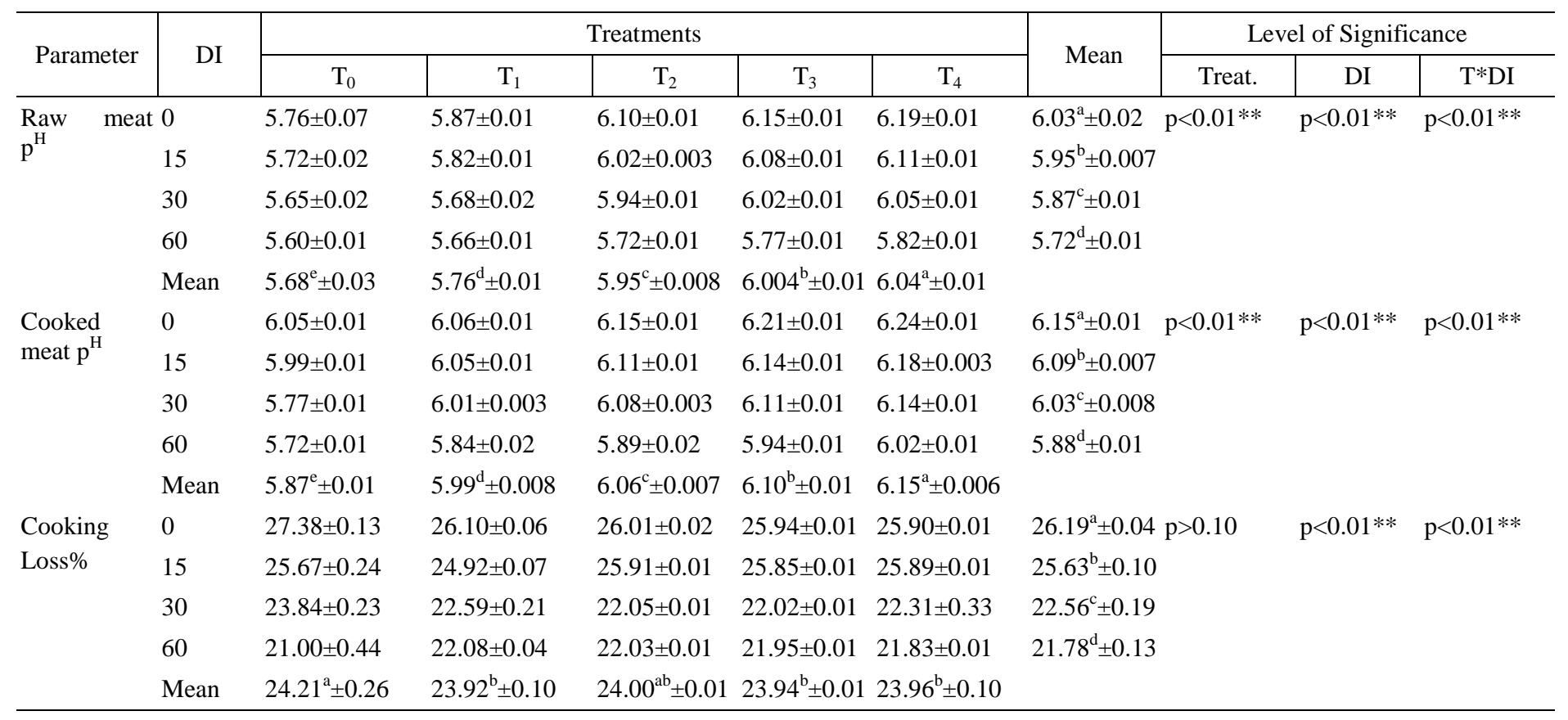


Table 4. Effect of Maringa oleifera leaf extract and BHA on biochemical parameters in beef meatball

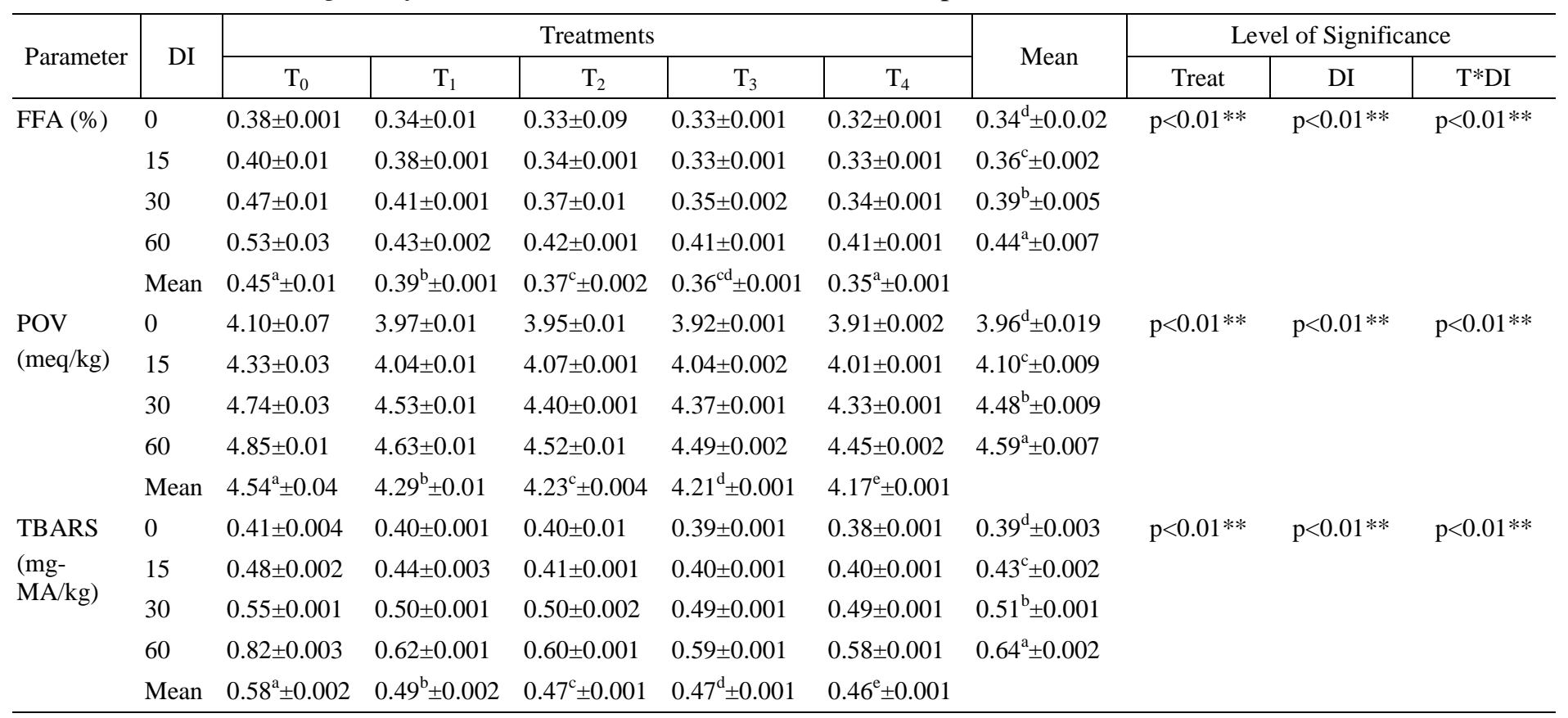


Table 5. Effect of Moringa oleifera leaf extract and BHA on different microbe's population in beef meatball

\begin{tabular}{|c|c|c|c|c|c|c|c|c|c|c|}
\hline \multirow{2}{*}{ Parameter } & \multirow{2}{*}{ DI } & \multicolumn{5}{|c|}{ Treatments } & \multirow{2}{*}{ Mean } & \multicolumn{3}{|c|}{ Level of Significance } \\
\hline & & $\mathrm{T}_{0}$ & $\mathrm{~T}_{1}$ & $\mathrm{~T}_{2}$ & $\mathrm{~T}_{3}$ & $\mathrm{~T}_{4}$ & & Treat & DI & $\mathrm{T}^{*} \mathrm{DI}$ \\
\hline \multirow{3}{*}{$\begin{array}{l}\text { TVC } \\
(\log \mathrm{CFU} \\
\left.\mathrm{g}^{-1}\right)\end{array}$} & 0 & $4.65 \pm 0.04$ & $4.57 \pm 0.04$ & $4.43 \pm 0.01$ & $4.37 \pm 0.02$ & $4.27 \pm 0.02$ & $4.45^{\mathrm{c}} \pm 0.03$ & $\mathrm{p}<0.01 * *$ & $\mathrm{p}<0.01 * *$ & $\mathrm{p}<0.01 * *$ \\
\hline & 60 & $5.45 \pm 0.04$ & $5.16 \pm 0.03$ & $4.69 \pm 0.01$ & $4.55 \pm 0.02$ & $4.44 \pm 0.02$ & $4.86^{\mathrm{a}} \pm 0.02$ & & & \\
\hline & Mean & $5.06^{\mathrm{a}} \pm 0.03$ & $4.83^{\mathrm{b}} \pm 0.03$ & $4.55^{\mathrm{c}} \pm 0.01$ & $4.45^{\mathrm{d}} \pm 0.02$ & $4.36^{\mathrm{e}} \pm 0.02$ & & & & \\
\hline \multirow{2}{*}{$\begin{array}{l}\mathrm{TCC} \\
(\log \mathrm{CFU} \\
\left.\mathrm{g}^{-1}\right)\end{array}$} & 60 & $1.02 \pm 0.01$ & $0.95 \pm 0.03$ & $0.85 \pm 0.02$ & $0.78 \pm 0.01$ & $0.72 \pm 0.002$ & $0.87^{\mathrm{c}} \pm 0.01$ & & & \\
\hline & Mean & $1.10^{\mathrm{a}} \pm 0.01$ & $1.05^{\mathrm{b}} \pm 0.02$ & $0.99^{c} \pm 0.01$ & $0.96^{\mathrm{d}} \pm 0.01$ & $0.91^{\mathrm{e}} \pm 0.02$ & & & & \\
\hline \multirow{2}{*}{$\begin{array}{l}\text { TYMC } \\
(\log \mathrm{CFU} \\
\left.\mathrm{g}^{-1}\right)\end{array}$} & 0 & $1.98 \pm 0.002$ & $1.85 \pm 0.02$ & $1.80 \pm 0.01$ & $1.72 \pm 0.01$ & $1.67 \pm 0.01$ & $1.79^{\mathrm{a}} \pm 0.01$ & $\mathrm{p}<0.01 * *$ & $\mathrm{p}<0.01 * *$ & $\mathrm{p}>0.38^{\mathrm{ns}}$ \\
\hline & 30 & $1.55 \pm 0.02$ & $1.38 \pm 0.01$ & $1.34 \pm 0.01$ & $1.27 \pm 0.004$ & $1.19 \pm 0.03$ & $1.34^{\mathrm{b}} \pm 0.012$ & & & \\
\hline
\end{tabular}




\section{CONCLUSIONS}

The study may be concluded that $0.3 \%$ of Moringa leaf extract as natural antioxidant can be used in beef meatballs preparation instead of synthetic antioxidant (BHA). In case of cooking loss at $0.2 \%$ Moringa leaf extract is more preferable than that of other treatment groups. On the basis of sensory evaluation, physicochemical properties, biochemical analysis and microbial assessment indicates that $0.3 \%$ Moringa leaf extract groups shows better results compare to synthetic antioxidant.

\section{ACKNOWLEDGEMENTS}

We would like to express our appreciation to the Bangladesh Agricultural University Research System (BAURES), Mymensingh for funding this research and their continuous encouragement to complete the study successfully.

\section{REFERENCES}

AOAC. (1995). Official methods of analysis. (16 ${ }^{\text {th }}$ Edition) Association of official Analytical Chemists. Washington, DC. USA.

Biswas, A.K., Keshri, R.C., and Bisht, G.S. (2004).Effect of enrobing and ant oxidants on quality characteristics of pre-cooked pork patties under chilled and frozen storage condition. Meat Science, 66, 733-741.

Fasseas, M.K., Mountzouris, C.K., Tarantilis, P.A., Polissiou, M., and Zervas, G. (2007). Antioxidant activity in meat treated with oregano and sage essential oils. Food Chemistry, 106, 1188-1194.

Fernández-López, J., Zhi, N., Aleson-Carbonell, L., Pérez-Alvarez, J.A., and Kuri, V. (2005). Antioxidant and antibacterial activities of natural extracts: Application in beef Meatballs. Meat Science, 69, 371-380.

Gonzalez, M.T.N.D., Boleman, R.M., Miller, R.K., Kefton J.T., and Rhee, K.S. (2008). Antioxidant properties of dried plum ingredients in raw and pre-cooked pork sausage. Journal of Food Science, 73, H63-H71.

Hayes, J. E., Allen, P., Brunton, N., O’Grady, M.N., and Kerry, J.P. (2010). Phenol Composion of in-vitro antioxidant capacity of four commercial phytochemical products: olive leaf extracts (Olea europaea L), lutein, sesame oil and ellagic acid. Food Chemistry, 126, 948-955.

Ikhlas, B., Huda, N., and Noryati, I. (2011).Chemical composition physicochemical properties of meatballs prepared from mechanically deboned quail meat using various types of flour. International Journal of Poultry Science, 10 (1), 30-37.

Jama, N., Muchenje, V., Chimonyo, M., Strydom, P.E., Dzama,, K., and Raats, J.G. (2008). Cooking loss components of beef from Nguni, Bonsmara and Angus steers. African Journal of Agricultural Research, 3 (6), 416-420.

Jung, S., Choe, J., Kim, B., Yun, H., Kruk, Z.A. and Jo, C. (2010).Effects of dietary mixture of gallic acid and linoleic acid on antioxidative potential and quality of breast meat from broilers. Meat Science, 86, 520-526. 
Lee, J.Y. and Kunz, B. (2005). The antioxidant properties of baechu-kimchi and freeze dried kimchi-powder in fermented sausages. Meat Science, 69, 741-747

Purnomo, A., and Rahardiyan, D. (2008). Indonesian traditional meatball: Review article Int. Food Research Journal, 15,101-108.

Sankhalkar, S., and Vrunda, V. (2016). Quantitative and qualitative analysis of phenolic and flavonoid content in moringa oleifera lam and ocimum tenuiflorum 1. Pharmacognosy Research, 8(1), 16-21.

Sharma, P., Jha, A.B., Dubey, R.S., and Pessarakli, M. (2012). Reactive oxygen species, oxidative damage and Antioxidative defence mechanism is plants under stressful conditions. Journal of Botany, 2012, 1-26.

Serdaroglu, M., Yldz, T.G., and Abrodimov, K. (2005).Quality of low-fat meatballs containing Legume flours as extenders. Meat Science, 70(1), 99-105.

Sreelatha, S., and Padma, P.R. (2009).Antioxidant Activity and Total Phenol Content of Moringa oleifera Leaves in Two Stages of Maturity. Plant Foods and Human Nutrition, 64, 303-311.

Verma, A.R., Vijayakumar, M., Mathela, C.S., and Rao, C.V. (2009). In vitro and in vivo antioxidant properties of different fraction of Moringa oleifera leaves. Food and Chemical Toxicology, 47, 2196-2201. 